\title{
ONDERWYS IN AFRIKA: ONTWIKKELING OF ONDERONTWIKKELING?
}

\author{
LINDA LE ROUX, Dept. Ontwikkelingsadministrasie, UNISA
}

\begin{abstract}
In this article the author first looks at the expectations held for education as a key to the development for under-developed African countries. The high correlation that is to be found between formal education and economic growth in Western countries has led to the fact that formal education has been regarded as the solution for the economic, political and cultural problems of Africa. Afier more than two decades, in the course of which formal education has been much touled, the problems supposed to have been solved by formal education are becoming worse.
\end{abstract}

According the author looks at the negative influence the present educational systems had on education. An important cause for this phenomenon is that the educational system of the colonial power is often imposed and maintained on the African country without being modified in any way, while currimula have not been adapted to local needs and conditions.

As a better solution for the educational problems of Africa it is suggested that greater stress be placed on basic and non-formal ectucation.

Vandag, 21 jaar na die Addis Ababa-konferensic, waartydens onderwys geïdentifiseer is as die sleutel tot die ontwikkeling van Derdewêreldlande, en meer spesifick Afrika, beklee onderwys nog steeds 'n sentrale posisie in die ont wikkelingsideologieë en -benaderings van hierdie lande. In'n poging om armoede uit te wis en die ekonomiese agterstandsgaping tussen arm en ryk lande te vernou ken Afrikalande tans nog steeds 'n gemiddeld van $15 \%$ van hulle begrotings aan die voorsiening en ontwikkeling van onderwysfasiliteite toe. In sommige Afrikalande word so veel as een derde van hulle ontwikkelingsbegrotings aan onderwys afgestaan, dikwels tot die nadeel van ander, ewe belangrike nasionale sektore soos die praktiese skepping van werksgeleenthede deur die stimulering van die informele en kleinsakesektore en soos die verbetering van die algemene gesondheidstoestand van die bevolking deur die skepping van meer en verbeterde gesondheidsfasiliteite.

Die cise wat aan onderwys as 'n ontwikkelingsinstrument gestel word, is

Koers, 47(3) 1982 
besonder hoog. Tog blyk dit, na 21 jaar waartydens universele en gratis formele onderwys gepropageer en bepleit is, dat onderwys nie besig is om aan hierdie verwagtings te voldoen nie en dat, in blote ckonomicse terme gercken, die gaping tussen die "have's" en die "have not's" nog steeds besig is om te vergroot.

Hierdie artikel poog om 'n feitclike uiteensetting te gee van die eise en verwagtings wat aan onderwys in die ontwikkelingsproses gestel word. In die tweede plek sal gekyk word na die negatiewe invlocd van die huidige onderwysstelsel op ontwikkeling, waaruit die afleiding inderdaad gemaak kan word dat die gevaar bestaan dat onderwys, in sy huidige vorm, eerder aanleiding kan gee tot die onderontwikkeling van die Afrikalande as die ontwikkeling daarvan. Ten slotte word aandag gegee aan die konsep "basiese onderwys" in nie-formelc onderwys as potensiële opheffers van minderontwikkeldheid.

\section{VERWAGTINGS GESTEL AAN ONDERWYS AS SLEUTEL TOT ONTWIKKELING}

In 1948 het die Algemene Vergadering van die Verenigde Nasies onderwys geïdentifiseer as een van die basiese menseregte, en sedert die eerste ontwikkelingsdekade het die leiers en bevolking van minderontwikkelde lande onderwys gesien as 'n sosiale en ekonomiese voordeel wat na alle streke van hulle lande cn na alle vlakke van die bevolking uitgebrei moes word. Onderwys sou instrumenteel wees in die verkryging van kennis, vaardighede en ' $n$ verandering in houdings wat as noodsaaklik beskou is om die nodige wetenskaplike kennis en opgeleide mannekrag vir die ontwikkeling en modernisering van 'n minderont wikkelde land te voorsien (Dejeni, 1980:1). Onderwys sou verder ook ongeletterdheid en tradisionele landboupraktyke uitwis, versnelde industrialisering stimulcer, politicke stabiliteit verseker en nasionale eenheid skep.

Ten einde hierdie verwagtings beter te begryp is dit nodig om twee van die vernaamste denkskole rakende onderwys van nader te beskou, naamlik die klassieke siening en die reformistiese siening.

Die klassieke denkrigting was, volgens Dejeni (1980:28), in die vyftigerjare besonder gewild onder nie net die teoretici van daardie jare nie maar ook onder hulpverleningsagentskappe en regeringsleiers van die meeste van die beter ontwikkelde lande. Volgens hierdie denkskool is onderwys in ekonomiese terme gesien waardeur investering in onderwys vir spcsifieke 


\section{Le Roux}

berocpe aanleiding sou gee tot 'n verhoogde vraag na opgeleides, wat op sy beurt tot modernisering en versnelde ont wikkeling lei. Hierdie siening het sy oorsprong gehad in die feit dat daar in Westerse lande 'n hoë korrclasie bestaan tussen formele onderwys en ekonomiese groei, en in die hoop dat hierdie korrelasie ook in minderontwikkelde lande geëwenaar kan word. Hierdie besondere standpunt van die klassieke fase het dus van die veronderstelling uitgegaan dat onderwys outomaties tot ekonomiese groei aanleiding sou gee en dat ekonomiese groci sinoniem was aan ontwikkeling. Die woorde van Harbison (aangehaal in Todaro, 1977:235) omskryf die bostaande stelling die duidelikste: “... human resources ... constitute the ultimate basis for wealth of nations. Capital and natural resources are passive factors of production, human beings are the active agents who accumulate capital, exploit natural resources, build social, economic and political organizations, and carry forward national development. Clearly, a country which is unable to develop the skills and knowledge of its people and to utilize them effectively in the national economy will be unable to develop anything else".

Gant (1979:75) onderskryf hierdie siening wanneer hy sê: "The quality of the human resources applied to economic development has a direct relationship to the pace and the level of that development". Nie net is die kwaliteit van die menslike bronne nie maar ook navorsing en die ontwikkeling van tegnologie belangrike funksics van onderwys. Ook is die toepassing van wetenskap en tegnologie nie toeganklik vir persone wat nie formele onderwys ondergaan het nie. Ten einde ekonomies te groei (en dus ook, volgens die klassieke standpunt, te ontwikkel) is 'n voldoende aantal gekwalifiseerde persone, tegnies opgeleides, bestuursvlakamptenare en entrepreneurs 'n voorvereiste.

Dit is uit bostaande dus duidelik dat onderwys, vanuit 'n ekonomiese standpunt gesien, besonder hoog geëvalueer word. Maar die klassieke siening het onderwys nie bloot vanuit 'n ekonomiese standpunt gesien nie. 'n Tweede, verbandhoudende klassieke sicning beskou onderwys vanuit 'n politiekc perspcktief. Daar word deur die voorstanders van hierdie siening geredeneer dat onderwys 'n sterk politieke elite sal voortbring wat lcierskapsposisies in dic land sal beklee en hierdeur ' $n$ bydrac tot die ontwikkeling van die land sal kan lewer (Dejeni, 1980:30). Coleman, 'n ondersteuner van hierdie siening, is van mening dat formele onderwys 'n positiewe bydrae tot die vorming van 'n moderne staat kan lewer, deurdat onderwys politieke sosialisering, politieke rekrutering en politieke integrasic sal inisieer en versnel (Coleman, 1965:18-32). 


\section{Onderwys in Afrika}

Gant (1979:76) onderskryf Coleman se siening wanneer hy aanvoer dat: "The lessons of the schoolroom and the associations with the educational system as a whole can contribute directly and heavily to the integration and national unity of a country, and especially a newly independent country, by emphasizing its common identitics of language, history and culture." Dat Gant se siening ictwat utopies is, is duidelik wanneer bostaande aanhaling in samchang gelces word met' $n$ artikel van Schoeman (1981:63-74) waarin die probleme van onderwys in $\Lambda$ frika, wat deur kulturele heterogeniteit gekenmerk word, uiteengesit word.

Waar onderwys egter wel 'n bydrae tot polit ieke ontwikkeling kan lewer, is deur dic oordra van kommunikasievaardighede wat onderliggend is aan'n begrip en aan declname aan 'n land se regering en sy politieke stelsel. 'n Geletterde bevolking sou ook beter daartoe in staat wees en meer geneigd wees om sy ekonomicse, sosiale en politieke waardes te definicer en te stimuleer as wat met 'n ongelctterde bevolking die geval is.

'n Derde terrein waarop onderwys 'n bydrae tot ontwikkeling vanuit 'n klassieke standpunt kan lewer, is op die kulturele gebicd. Hoewel daar vroeër kortliks gewys is op die feit dat onderwys kulturele ongelykheid nie kan uit wis nie, is Goldthorpe (1967:202) se bewering: "It is clear... that one of the major tasks in the development of education in poor, non-western countries is seen as that of harmonizing two cultures - or at least trying to reduce the dissonance between them", nie heeltemal ongegrond is nie. Onderwys kan wel' $n$ beperkte bydrae lewer deur onderlinge begrip onder verskeie taal-, kultuur- en etniese groepe te kweek.

Onderwys kan egter 'n belangrike versoeningstaak op kulturele gcbied verrig, naamlik in gevalle waar daar 'n potensiële botsingsmoontlikheid bestaan tussen tradisioncle kultuur, wat soms die ontwikkelingsweg versper, en die ont wikkelingsproses. Onderwys kan op hierdie gebied 'n vernuwingsrol speel deur die kultuur 'n klemverskuiwing te laat ondergaan wat die ontwikkeling van die gemecnskap sal bevorder.

In die scwentigerjarc het die klem grootliks begin verskuif na wat Dejeni (1980:31) klassifiseer as die rcformistiese siening aangaande onderwys se rol in ontwikkeling. Volgens hierdie siening kan onderwys 'n bydrae tot ontwikkeling lewer mits onderwys deur 'n omvattende program van mannekragbeplanning gerugsteun word. Die onderliggende argument van hierdie standpunt is dat die meeste van die minderontwikkelde lande 'n tekort aan opgelcide mannekrag het en dat die ckonomie van hierdie land 


\section{Le Roux}

nic die vermoë het om persone wat in algemene rigtings opgelei is te absorbeer nie. Deur mannekragbeplanning aan onderwysvoorsiening te koppel word 'n analise gemaak van die minimum bchoeftes vir die teenswoordige sowel as vir die toekoms, gevolg deur die opleiding van persone wat deur die ekonomie geabsorbeer kan word. In navolging van die reformist iese st andpunt word onder andere aandag gegee aan die struktuur van die bestaande onderwysstelsel van 'n land en word daar voorsiening gemaak vir die verdere verskaffing van tegniese opleiding op sekondêre vlak.

Uit die voorgaande is dit duidelik dat onderwys deurgaans 'n sentrale posisie in die ontwikkelingsproses beklee en dat die verwagtings wat daaraan gekoppel word, besonder hoog is. Dit is egter ook waar dat, ondanks die pogings wat aangewend word om universcle onderwys in Afrika te voorsien, onderwys nic aan hierdie hoë verwagtings voldoen nie en dat die meerderheid van Afrika se inwoners nog ongeletterd is en 'n lae lewenstandaard het. Die onvermoẻ van onderwys om sy ontwikkelingspotensiaal te verwesenlik kan egter nie net tocgeskryf word aan faktore soos te min en swak opgeleide onderwysers, 'n hoë skolier tot onderwyserverhouding en 'n hoë druipsyfer nie. Ki-Zerbo (1974:95) poneer die volgende stelling in hierdie verband: "The school in many underdeveloped countries is a reflection and a fruit of the surrounding underdevelopment, from which arises its deficiency, its quant it ative and qualitative poverty. But little by little, and there lies the really serious risk, the school in these underdeveloped countries risks becoming in turn a factor of underdevelopment".

\section{ONDERWYS EN ONDERONTWIKKELING}

Die mees voor die hand liggende oorsaak van onderwys as ' $\mathrm{n}$ bydraende faktor in die onderontwikkeling van Afrikalande is gelee in die koloniale erfenis van hierdie lande en in die uitwerking wat 'n koloniale verlede op die ontwikkeling van hulle onderwysstelsels gehad het. Die onderwysstelsels van Afrikalande is geskoei op dié van hulle voormalige koloniale corheersers, wat mutatis mutandis op hulle oorgedra is sonder inagname van en aanpassing by die inwoners van die betrokke land se kultuur.

Die leerplanne van dic moederland was ingestel op formele onderrig, en hierdie onderrigdoelwitte was nie noodwendig die geskikste vir die situasie in die Afrikalande nic. Nietemin noem Ward (1974:xvi) die interessante gegewe dat die oorgrote meerderheid van die Afrikalande se bevolkings na onafhanklikwording ten gunste van die voortbestaan van die koloniale 


\section{Onderwys in Afrika}

moondhede se onderwysstelsels was. Die rede hiervoor was dat die massas geen plaasvervanger wou hê vir daardie oorgeërfde stelsel wat soveel sosiale en ekonomiese voordele vir die nasionale elites gebring het nie. Ward (1974; xvi) noem dat dit dus nie verbasend is dat die onderwysstelsels wat vandag nog in talle Afrikalande aangetref word, so nou met die voorafgaande stelsels oorcenstem nie. Hierdie koloniale stelsels is in der waarheid eerder uitgebrci as wat hulle verander is.

'n'lweede aspek wat tot onderontwikkeling kan Ici en wat nou by die vorige punt aansluit, is die verskynsel dat die kurrikulum van die skole in Afrika nie by die plaaslike omstandighede aangepas is nie. In baie van die skole in Afrikalande word vakke soos Geskiedenis en Aardrykskunde nog steeds gebaseer op die geskiedenis en aardrykskunde van die voormalige Britse en Franse koloniale moondhede. Ki-Zerbo (1974:99) voer aan dat, wanneer'n mens in ag neem dat geskiedenis die kollektiewe geheue van 'n volk is, 'n student van sy eie omgewing, volkseie en volksgenote vervreem word as hy nie sy cie land se geskiedenis en aardrykskunde bestudeer nie. Ook hou die verskynsel dat onderrig dikwels nog in 'n vreemde taal aangebied word, negatiewe implikasies in en dien dit ook as ' $n$ instrument van vervreemding van die student se eie.

'n Derde faktor wat met die bogenoemde twee punte verband hou, is geleè in die feit dat studente opgelei word vir witboordjiewerk, waarvan daar nie genoeg werksgeleenthede in die land geskep kan word nie. Die aantal geleerde werkloses in Afrika neem jaarliks toe. Harrison (1981:315) skryfdie verskynsel aan die volgende toe: "Today a school certificate is seen as a one-way ticket out of the poverty and depression of rural life and the curse of manual labour", en verder aan (1981:319-320): "As long as "academic freedom" exists, students are liable to choosc courses according to their expected earnings on graduation, rather than according to their country's manpower needs". Bostaande hou ernstige werkloosheids- en onderindiensnameprobleme in, aangesien verwagtings en sosiale norme opgeleide persone daarvan weerhou om werk te aanvaar wat die land realisties kan voorsien.

'n Vierde belangrike faktor is die ongelyke voorsiening van onderwysfasiliteitc, wat geredeliker beskikbaar is in stedelike as in landelike gebiede. Die meeste van die Afrikalande se bevolkings wat ongeletterd is, woon ju is in die landelike gebiede en het nie gclyke toegang tot onderwysgelcenthede nie. Lipton het na hierdie verskynsel verwys as die "urban bias of government policy in the 'Third World". 


\section{Le Roux}

Onderontwikkeling word in die vyfde plek ook bevorder deur die geweldige hoë finansiële koste wat aan onderwys, en veral formele onderwys, verbonde is. $\mathrm{Ki}$-Zerbo (1974:96) noem die voorbeeld van Bo-Volta, waar daar tans 17-18 persent van die land se nasionale begrotng aan onderwys bestee word. Om aan alle kinders in Bo-Volta onderwys te verskaf sal 'n paar keer die nasionale begroting verg. Wanneer so' $n$ groot persentasie van die begroting aan onderwys bestee word, gebeur dit dat daar ander sektore is wat afgeskecp word, en ontstaan die vraag of onderwysonkoste nie eercler besnoei moet word nie.

'n Sesde faktor wat tot onderontwikkeling aanleiding kan gee, is die sogenaamde "brain drain"-verskynsel. 'n Tekort aan opgeleide mannekrag ontstaan in landelike gebiede, maar ook in die lande van herkoms, wanneer opgeleide persone na die stedelike gebiede of ander (verder ontwikkelde) lande stroom om daar 'n hoër salaris te verdien. Hierdie verskynsel kom toenemend in Derdewêrcldlande, en veral in Afrikalande, voor en kan ernstige implikasies inhou vir die ontwikkeling van die land of gebied van herkoms, veral wanneer in ag geneem word die insette wat nodig was om die persone op te lei.

'n Laaste faktor wat negaticwe implikasies vir die ontwikkeling van Afrikalande inhou, is die kwalifikasiespiraal, of, soos Dore (1976:5) dit noem, "educational inflation". Die groot klem wat daar in Afrikalande op formele onderrig geplaas word, gee daartoe aanleiding dat daar grootskaalse werkloosheid onder opgcleide mense voorkom as gevolg van 'n tekort aan werksgeleenthede vir hierdie geskoolde en hoogs geskoolde persone. Dit gebeur dus dat, wanneer daar 'n oorvoorsiening aan persone met ' $n$ bepaalde kwalifikasie is, werkgewers 'n onnodige hoë vlak van onderwys kan verwag, wat aanleiding gee tot die kwalifikasiespiraal of, soos Kirk-Greene dit noem, die "qualificationit is syndrome". Volgens Dore is die ironie van hierdie verskynsel dat hoe hoër werkloosheid onder geskoolde mense styg en hoe waardeloser sertifikate word, hoe sterker word die druk vir die uitbreiding van onderwysfasiliteite.

In die lig van die voorgaande beskrywings ontstaan die vraag of die huidige onderwysstelsel inderdaad 'n bydrae tot ontwikkeling kan lewer en of dit nodig en realisties is dat Afrikalande sulke groot persentasies van hulle begrotings aan onderwys afstaan. Is die nadele wat onderwys vir ontwikkeling inhou, nie vecl groter as die positiewe bydrae wat dit kan lewer nie? 
Politici, teoretici en onderwysbeplanners van binne en buite Afrika het onlangs eers begin om, in die lig van hierdie vrae, die "cult of formal cducation" (Torado, 1977:236) te bevraagteken. Daar word vandag toenemend ondersoek ingestel na basiese onderwys en nie-formele onderwys as metories om minderontwikkeldheid op te hef.

\section{DIE BYDRAE VAN BASIESE EN NIE-FORMELE ONDERWYS}

Basiese onderwys word gedefinicer in terme van minimum leerbchoeftes en "is particularly important in lower-income countries where the provision of a minimum education is a necessary condition for the effective participation of the masses in productive life as well as in the social and political process" (World Bank, 1974:28). Basiese onderwys word sesien as aanvullend by die formele onderwysstelsel en "is intended to provide a functional, flexible and low-cost education for those whom the formal system cannot yet reach or has already passed by" (World Bank, 1974:29). Die teikengroep van basiese onderwys is nie noodwendig kinders van skoolgaande leeftyd nie maar sluit ook jeugdiges en volwassencs in.

Die begrip "minimum leerbehoeftes" kan vergelyk word met die term "poverty line", wat na die minimum gesinsinkomste verwys. UNICEF (in World Bank, 1974:30) definicer minimum leerbehoeftes as "a threshold level of learning required for participation in economic, social and political activities". Hierdie noodsaaklike leerbehoeftes sluit funksionele geletterdheid in asook kennis cn vaardighede vir produkticwe akt iwiteit, gesinspasiëring en gesondheid, kindersorg, sanitasie en kennis wat vir burgerlike deelname nodig is.

Daar is egter reeds sterk kritiek geopper teen die basiese onderwysbenadering. Bray (1981:558-561) nocm onder anderc die oorweging dat die konsepte wat gebruik word om hierdie benadering te definieer en te omskryf, so vaag is dat die standaard van sulke programme nie net van land tot land nie maar ook van strcek tot streek verskil.

'n Tweede moontlikheid wat tans wêreldwyd aandag geniet, is die stelsel van nie-formele onderwys. Nie-formele onderwys verwys na enige georganiseerde, sistematiese onderwysaktiwiteil wat buite die raamwerk van die formele onderwysstelsel uitgevoer word met die doel om gesclekteerde lecrtipes oor te dra aan 'n spesifieke subgroep in die bevolking, kinders sowel as volwassencs (Dejeni, 1980:19). 


\section{Le Roux}

Coombs \& $\Lambda$ hmed (in Dejeni, 1980:43) sien nie-formele onderwys as "... all organized activitics designed to improve the knowledge and the skills of farmers, artisans, craft workers, and small entrepreneurs in rural arcas in order to increase their output, productivity or level of living". Hierdie twee skrywers huldig die siening dat nie-formele onderwys hoofsaaklik op die landelike inwoners gerig behoort te wees, omdat ongeveer 70 persent van Afrika se bevolking hulle daar bevind, en uit die aanhaling is dit ook duidelik dat hulle dic omvang van nie-formele onderwys as feitlik onbeperk sien.

Die mees voor die hand liggende bydrae van nie-formele onderwys in $A$ frika is om aan die volwasse bevolking geletterdheidsprogramme te bied en om met in-diens-opleidingsprogramme te begin. Niehoff (in Dejeni, 1980:46) dig egter aan nie-formele onderwys 'n nog omvattender taak toe, en hy som dit soos volg op: “... a method of defining developmental needs and formulating programs of communication and education to increase the participation of the rural poor in agricultural production, and in programs of nutrition, rural health delivery systems, family planning and other programs designed to improve their productivity and welfare, if not their survival".

Die waarde van nic-formele onderwys lê verder daarin dat dit vcel goedkoper sal wees as formele onderrig aangesien die programme van korter duur is, dic skcpping van fasiliteitc relatief goedkoop sal wees, aangesicn daar van bestaande fasiliteite gebruik gemaak kan word (bv. gemeenskapsale) en dat die personeel daarby betrokke nie noodwendig uit te veel professionele persone hoef te bestaan nie. Die opleiding sal in 'n mate van groter waarde wees, aangesien die inhoud van die kursusse op die oordra van vaardighede gerig sal wees. Ten cinde met welslae toegepas te word is dit egter nodig dat nie-formele onderwys buigsaam sal wees sodat dit aanpasbaar is by die spesifieke behoeftes van die teikengroep. Dit is voorts ook nodig dat nie-formele onderwysprogramme by die betrokke land se ontwikkelingsbehoeftes en -strategie geïntegreer sal wees.

\section{SLOTGEDAGTES}

Hoewel onderwys 'n positiewe bydrae het wat dit in Afrika op politieke, sosiale en kulturele gebied kan lewer, het dit oor die afgelope paar dekades duidelik gcblyk dat dic huidige onderwysstelsel ook ernstige negatiewe implikasies vir ontwikkeling inhou en dat die huidige onderwysgebruike inderdaad tot die onderontwikkeling van $\Lambda$ frika kan bydra. Dat claar wel praktiese metodes is waardeur die genoemde probleme opgelos kan word, is nie te betwis nie. In hierdie artikel is slegs aan twee moontlikhede kortliks 


\section{Onderwys in Afrika}

aandag gegee, naamlik basicse onderwys en nic-formele onderwys. Indien daar genocgsame navorsing oor hierdie twee voorstclle gedoen word en indien die moontlikhede hiervan ten volle benut word, kan hulle met formele onderwys meewerk om die mensepotensiaal van Afrika ten volle tc benut en te ontwikkel.

\section{BIBLIOGRAFIE}

BR $\Lambda Y$, M. 1981. Policies and progress towards universal primary education. Journal of modern African sludies, 19(4).

COLEMAN, J.S. 1965. Education and political development. Princeton : Princeton University Press.

DEJENI, A. 1980. A broader concept of development and the role of non-formal education: analysis of three rural development projects. $\Lambda$ nn Arbor : Univ. Microfilms.

DORE, R. 1976. The diploma disease: cducation, qualification and development. London: Allen \& Unwin.

GANT, G.F. 1979. Development administration; concepts, goals, methods. Madison : Univ. of Wisconsin Press.

GOLDTHORPE, J.E. 1967. The sociology of the Third World: disparity and involvement. Cambridge : Cambridge University Press.

HARRISON, P. 1981. Inside the World. The anatomy of poverty. Middlesex : Penguin Books.

KI-ZERBO, J. 1974. Education and development. (In Ward, F.C. ed. Education and development reconsidered; The Bellagio conference papers. New York : Pracger.)

SCHOEMAN, S. 1981. Education and training in multi-cultural socicties: the feedback from Africa. Journal of contemporary African studies, 1(1).

TORADO, M.P. 1977. Economic development in the Third World. I,ondon : I.ongman.

WARD, F.C. ed. 1974. Education and development reconsidered; The Bellagio conference papers. New York : Praeger.

WORI.D BANK. 1974. Education. Sector working paper. Washington : World Bank. 